\title{
Cytogenotoxic effects of two potential anticancer Ruthenium(III) Schiff Bases complexes
}

Izet Eminovic ${ }^{*}$, Emira Kahrovic ${ }^{2}$, Aner Mesic ${ }^{1}$, Emir Turkusic², Dzenana Kargic ${ }^{1}$, Adnan Zahirovic ${ }^{2}$, Zana Dolicanin ${ }^{3}$

${ }^{1}$ Department of Biology, Faculty of Science, University of Sarajevo, Sarajevo, Bosnia and Herzegovina, ${ }^{2}$ Department of Chemistry, Faculty of Science, University of Sarajevo, Sarajevo, Bosnia and Herzegovina, ${ }^{3}$ Department of Biomedical Sciences, State University of Novi Pazar, Novi Pazar, Serbia

\begin{abstract}
Introduction: Treatment of cancer has been subject of great interest. Researchers are continuously searching for new medicines. In this sense, ruthenium complexes have big potential. Some evidences suggest that ruthenium compounds possess anticancer activities. We synthesized two recently published ruthenium(III) complexes with bidentate $\mathrm{O}, \mathrm{N}$ and tridentate $\mathrm{O}, \mathrm{O}, \mathrm{N}$ Schiff bases derived from 5-substituted salicylaldehyde and 2-aminophenol or aniline. These compounds showed affinity for binding to the DNA molecule, however, insufficient data are available regarding their possible toxic effects on biological systems.
\end{abstract}

Methods: In the present study we evaluated genotoxic, cytotoxic, and cytostatic effects of $\mathrm{Na}\left[\mathrm{RuCl}_{2}\left(\mathrm{~L}^{1}\right)_{2}\right]$ and $\mathrm{Na}\left[\mathrm{Ru}\left(\mathrm{L}^{2}\right)_{2}\right]$, using the Allium cepa assay.

Results: Different toxic effects were observed depending on the substance, tested concentration, and endpoint measured. In general, the tested compounds significantly lowered the root growth and mitotic index values as compared to the control group. Additionally, a wide range of abnormal mitotic stages, both clastogenic and non-clastogenic were observed in the treated cells. $\mathrm{Na}\left[\mathrm{RuCl}_{2}\left(\mathrm{~L}^{1}\right)_{2}\right]$ significantly increased the frequency of sticky metaphases, chromosome bridges, micronuclei, impaired chromosome segregation, as well as number of apoptotic and necrotic cells over the controls. In contrast, $\mathrm{Na}\left[\mathrm{Ru}\left(\mathrm{L}^{2}\right)_{2}\right]$ did not show significant evidence of genotoxicity with regard to chromosome aberrations and micronuclei, however, significant differences were detected in the number of apoptotic and necrotic cells when the highest concentration was applied.

Conclusions: In this study we demonstrated antiproliferative effects of $\mathrm{Na}\left[\mathrm{RuCl}{ }_{2}\left(\mathrm{~L}^{1}\right)_{2}\right]$ and $\mathrm{Na}\left[\mathrm{Ru}\left(\mathrm{L}^{2}\right)_{2}\right]$. At clinical level, these results could be interesting for further studies on anticancer potential of the ruthenium(III) complexes using animal models.

Keywords: Ruthenium; Schiff bases; anticancer agents; apoptosis; chromosome aberrations; cytogenotoxic effects

\footnotetext{
*Corresponding author: Izet Eminovic, Department of Biology, Faculty of Science, University of Sarajevo, Zmaja od Bosne 33-35, 71000 Sarajevo, Bosnia and Herzegovina, Tel.: +387(0)33723741, Fax: +387(0)33649359. E-mail: izet.eminovic@pmf.unsa.ba
}

Submitted: 01 June 2016/Accepted: 15 July 2016

DOI: http://dx.doi.org/10.17532/jhsci.2016.357

UNIVERSITY OF SARAJEVO FACULTY OF HEALTH STUDIES (c) 2016 Izet Eminovic et al.; licensee University of Sarajevo - Faculty of Health Studies. This is an Open Access article distributed under the terms of the Creative Commons Attribution License (http://creativecommons.org/licenses/by/2.0), which permits unrestricted use, distribution, and reproduction in any medium, provided the original work is properly cited. 


\section{INTRODUCTION}

In the past few decades, a large number of studies published data on a wide range of synthesized ruthenium-containing agents which have been tested for potential antitumor activity (1). Ruthenium preferentially accumulates in neoplastic rather than normal tissues possibly by binding to transferrin receptors, after which transferrin-ruthenium complexes are transported into tumor cells $(2,3)$. Different ruthenium oxidation states (II, III, and IV) are all accessible under physiological conditions (4). Ruthenium(III) (Ru[III]) complexes appear to be more biologically inert than related $\mathrm{Ru}$ (II) and (IV) complexes (5). Moreover, ruthenium remains in relatively inactive $\mathrm{Ru}$ (III) oxidation state until it reaches the neoplastic cell. In such tissues where there is higher acidity and lower oxygen content when compared to the healthy tissues, reduction of the $\mathrm{Ru}$ (III) and (IV) complexes to the more reactive $\mathrm{Ru}(\mathrm{II})$ complex occurs $(5,6)$. Some ruthenium agents show significant efficacy against tumor metastases by the inhibition of cancer cell detachment $(7,8)$. NAMI-A and KP1019 are the only two Ru(III) complexes which have been described in the literature and are currently involved in human clinical trials (9). While NAMI-A has a specific anti-metastatic activity and low cytotoxicity, KP1019 demonstrates significant cytotoxicity by inducing apoptosis in human tumors $(6,10)$. Furthermore, ruthenium possesses the ability to mimic iron in binding to serum transferrin and albumin (11). Since it has been previously reported that ruthenium is transferred into cells by transferrin, it appears that this transport is more efficient when transferrin is saturated with iron (12). Additionally, it is believed that the ability of ruthenium to mimic iron in binding to biological molecules leads to the general low toxicity of ruthenium drugs (13). Several in vitro studies confirmed the ability of Ru compounds to bind to the DNA molecule (14).

Ruthenium compounds showed prominent catalytic and biological activity $(15,16)$. Well-known antimetastatic drug NAMI-A, Imidazolium trans-[tetrachloro(dimethylsulfoxide- $\mathrm{K} S$ ) (imidazole- $\kappa N)$ ruthenate(III)] is currently in third phase of human clinical trials, while compounds like ICR (NAMI-A indazole analog) and KP1019, Indazolium trans-[tetrachlorobis(indazole- $\mathrm{\kappa} N$ )
ruthenate(III)] are also prominent candidates for biological application $(3,16,17)$. Ruthenium complexes have several advantages over other platinum metals: (i) several oxidation states $(+2,+3,+4)$ are physiologically accessible, (ii) possibility of iron mimicking, (iii) binding to plasma proteins, especially transferrin, (iv) possibility of preparation of pro-drugs which are activated by reduction or by hydrolysis in cancer cells, (v) lower cytotoxicity towards normal cells, (vi) higher selectivity to cancer cells, (vii) activity of its compounds is not limited to DNA binding, signaling pathways and enzyme inhibition are also included. Schiff bases derived from salicylaldehyde and aromatic amines are stable stereochemically flexible mono- or dibasic polydentate $O, N$-donor ligands, which showed antibacterial and antiviral activity making them good candidates for coordination on metals $(18,19)$. Here we report in vitro cytotoxicity and genotoxicity of two ruthenium(III) complexes with Schiff base, sodium dichlorobis $(N$-phenyl-5-chlorosalicylideneiminato- $\left.{ }^{2} O N\right]$ ruthenate(III) and sodium bis[ $N$-2-oxyphenyl-5-nitrosalicylideneiminato- $\mathrm{K}^{3} \mathrm{ONO}$ ] ruthenate(III) hereinafter $\mathrm{Na}\left[\mathrm{RuCl}_{2}\left(\mathrm{~L}^{1}\right)_{2}\right]$ and $\mathrm{Na}\left[\mathrm{Ru}\left(\mathrm{L}^{2}\right)_{2}\right]$ respectively, towards Allium cepa meristematic root cells. Additionally, we included ethidium bromide, a known DNA intercalator.

Ethidium bromide [(3,8-diamino-5-ethyl-6-phenyl phenanthridinium bromide)] is widely used to probe DNA structure. It binds to DNA and slips between adjacent base pairs causing stretch of double DNA helix (20). The intercalator ethidium bromide (EtBr) represents a four-ringed aromatic molecule with three of the rings being conjugated. It has been reported that the strong mode of binding of $\mathrm{EtBr}$ to DNA results in the intercalation of the planar phenanthridium ring between adjacent base pairs on the DNA duplex (21). When intercalated into DNA, ethidium bromide increases the distance between the base pairs by $0.3 \mathrm{~nm}$, unwinds the double DNA helix by $26^{\circ}$ until the DNA duplex completely unfolds at a critical dye concentration. When $\mathrm{EtBr}$ concentration is further increased, the DNA double helix begins to wrap again in the opposite direction $(21,22)$. Furthermore, $\mathrm{EtBr}$ modifies its light-absorbing properties and therefore its fluorescence (23).

Plants appear to be very sensitive to heavy metals (24). Allium cepa assay is standardized test 
for studying cyto- and genotoxic effects of substances on chromosomes and cell division $(25,26)$. Furthermore, A. cepa is widely used as an assay for biomonitoring of environmental pollutants (27). In addition to its sensitivity, cost-effectiveness and good correlation with mammalian test systems, the $A$. cepa assay gives some additional advantages which enable both macroscopic and microscopic endpoints to be measured reliably $(25,28)$.

Therefore, the main objective of the present study is to evaluate, by means of the $A$. cepa assay, the cyto- and genotoxic effects of $\mathrm{Na}\left[\mathrm{RuCl}_{2}\left(\mathrm{~L}^{1}\right)_{2}\right]$, $\mathrm{Na}\left[\mathrm{Ru}\left(\mathrm{L}^{2}\right)_{2}\right]$, and $\mathrm{EtBr}$.

\section{METHODS}

\section{Chemicals}

$\mathrm{Na}\left[\mathrm{RuCl}_{2}\left(\mathrm{~L}^{1}\right)_{2}\right]$ and $\mathrm{Na}\left[\mathrm{Ru}\left(\mathrm{L}^{2}\right)_{2}\right]$ were prepared according to previously published procedures. The synthesized compounds were characterized based on elemental analysis, ${ }^{1} \mathrm{H}$ nuclear magnetic resonance (NMR), MALDI-TOF (matrix-assisted laser desorption/ionization/time-of-flight) mass spectra, cyclic voltammograms, and electronic spectra $(29,30)$. Ethidium bromide (CAS No. 1239-45-8) was purchased from SigmaAldrich (St. Louis, USA). Stock solutions of the test substances were prepared in dimethyl sulphoxide (DMSO) and kept at room temperature in the dark. All other chemicals used were of the highest grade commercially available.

\section{Experimental procedures and root growth}

A. cepa bulbs were grown in the dark at a temperature of $25 \pm 0.5^{\circ} \mathrm{C}$ in incubator Nahita 636/2 (Beriain, Navarra - Spain) for 48 hours. The onion bulbs (Allium cepa L.) were placed in glass vessels filled with tap water, which was renewed every 24 hours. The experimental procedures started after an incubation period of 48 hours by use of a series of three bulbs for each concentration and control group. The test concentrations of $\mathrm{Na}\left[\mathrm{RuCl}_{2}\left(\mathrm{~L}^{1}\right)_{2}\right], \mathrm{Na}\left[\mathrm{Ru}\left(\mathrm{L}^{2}\right)_{2}\right]$, EtBr, and DMSO $(6.25 ; 12.50 ; 25 ; 50 \mu \mathrm{g} / \mathrm{ml})$ were selected and prepared with tap water. At those concentrations, we incubated the onion bulbs for the next 48 hours. Fresh tap water was used as control group for all test compounds.

\section{Macroscopic parameters}

After an incubation period of 48 hours, before the treatment of the A. cepa bulbs with the test substances, root lengths were measured as previously described by Fiskesjö (31), after which the bulbs were exposed for 48 hours to the test solutions. At the end of the exposure period, the length of the roots from the experimental sets and control was also measured.

\section{Microscopic parameters}

A. cepa bulbs were exposed to the test solutions for 48 hours under the laboratory conditions as described above. At the end of the exposure period, root tips from each bulb were excised and fixed in ethanol/glacial acetic acid $(3: 1, \mathrm{v} / \mathrm{v})$ and kept at $4^{\circ} \mathrm{C}$ within 24 hours. After hydrolysis for 15 minutes in $5 \mathrm{M} \mathrm{HCl}$ at room temperature, the root tips were placed into distilled water. Thereafter, apical $2 \mathrm{~mm}$ of the root were cut and placed on clean glass slide in a drop of $2 \%$ acetorcein, and then squashed. For each tested concentration of all substances and control one slide per bulb was prepared. Cytogenetic analysis included determination of the mitotic index (MI), scoring of chromosome aberrations (CAs) and micronuclei $(\mathrm{MNi})$ as biomarkers of genotoxicity, as well as counting apoptotic and necrotic cells as cytotoxicity endpoints. The MI was calculated as the ratio between the number of cells in cell division and the total number of cells analyzed, counting 1000 cells per slide. By observing 1000 interphase cells per slide for each concentration, the frequencies of micronuclei were determined. Chromosome aberrations were scored in 100 mitotic cells for each bulb. Apoptosis and necrosis were analyzed separately scoring 1000 cells per slide and were considered as cytotoxicity endpoints.

\section{Statistical analysis}

Statistical analysis of the data was performed using one-way ANOVA with the post-hoc multiple comparison test (Bonferroni) in terms of determining differences between test compounds and control group for all analyzed parameters. Differences were considered statistically significant at $p<0.05$ level. All statistical analyses were conducted by use of Microsoft Excel 2010 (Microsoft Corporation) and GraphPad Prism 6.0 for Windows (GraphPad Software Inc., USA). 


\section{RESULTS}

\section{Inhibition of $\boldsymbol{A}$. cepa root growth}

All compounds showed statistically significant reduction of the root growth compared to the control group (Table 1). At the same time, DMSO caused significant decrease in root length compared to the controls.

\section{Genotoxicity and cytotoxicity in A.cepa root meristems}

Exposure to the different concentrations (6.25; $12.5 ; 25 ; 50 \mu \mathrm{g} / \mathrm{ml})$ of all the test compounds significantly inhibited the MI (Table 2) in the root tip cells of $A$. серa. There were significant differences in the MI values compared to the control bulbs for all treatments, including DMSO.

As for the measured genotoxic endpoints, $\mathrm{Na}\left[\mathrm{RuCl}_{2}\left(\mathrm{~L}^{1}\right)_{2}\right]$ showed statistically significant differences in the frequency of micronuclei $(\geq 12.5 \mu \mathrm{g} / \mathrm{ml})$, stickiness and chromosome missegregation $(6.25 \mu \mathrm{g} / \mathrm{ml})$, as well as for chromosome bridges $(6.25 ; 50 \mu \mathrm{g} / \mathrm{ml})$ compared to the control group (Table 3). On the other hand, $\mathrm{Na}\left[\mathrm{Ru}\left(\mathrm{L}^{2}\right)_{2}\right]$ did not significantly induce any of the genotoxic parameters analyzed. EtBr increased the frequencies of sticky metaphases and chromosome bridges at the 6.25 and $25 \mu \mathrm{g} / \mathrm{ml}$ concentrations over the control values. At the lowest concentrations $(\leq 12.5 \mu \mathrm{g} / \mathrm{ml})$ DMSO showed an increase in the frequency of chromosome missegregation compared to the control group. Furthermore, DMSO $(25 \mu \mathrm{g} / \mathrm{ml})$ induced frequent appearance of micronuclei in mitotic A. cepa root cells. When assessing cytotoxic parameters, it was found that $\mathrm{Na}\left[\mathrm{RuCl}_{2}\left(\mathrm{~L}^{1}\right)_{2}\right](\geq 25 \mu \mathrm{g} / \mathrm{ml})$ and $\mathrm{Na}\left[\mathrm{Ru}\left(\mathrm{L}^{2}\right)_{2}\right](50 \mu \mathrm{g} / \mathrm{ml})$ significantly increased the frequency of both apoptotic and necrotic cells over the control values (Figure 1). On the other hand, $\mathrm{EtBr}$ and DMSO at the same concentrations $(\geq 25 \mu \mathrm{g} / \mathrm{ml}$ ) showed statistically significant differences only for the frequency of necrotic cells when compared to the control group.

\section{DISCUSSION}

Ruthenium complexes with Schiff bases are extensively studied mainly in the light of their catalytic and biological activity. Schiff bases are organic

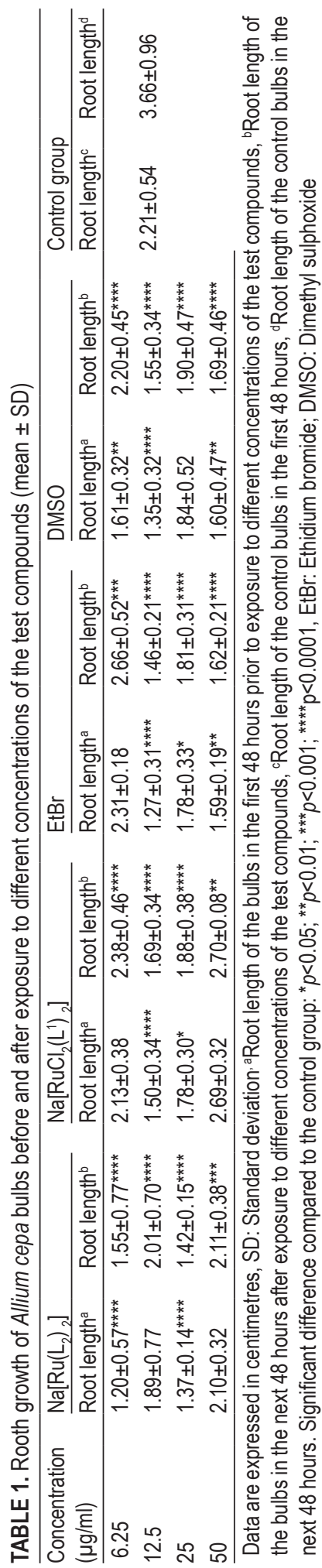


TABLE 2. Mitotic index in meristematic cells of Allium cepa exposed to different concentrations of the test compounds for 48 hours (mean \pm SD)

\begin{tabular}{lccccc}
\hline $\begin{array}{l}\text { Concentration } \\
(\mu \mathrm{g} / \mathrm{ml})\end{array}$ & $\begin{array}{c}\mathrm{Na}\left[\mathrm{Ru}\left(\mathrm{L}^{2}\right)_{2}\right] \\
\mathrm{Ml}\end{array}$ & $\begin{array}{c}\mathrm{Na}\left[\mathrm{RuCl}\left(\mathrm{L}^{1}\right)_{2}\right] \\
\mathrm{Ml}\end{array}$ & $\begin{array}{c}\mathrm{EtBr} \\
\mathrm{Ml}\end{array}$ & $\begin{array}{c}\mathrm{DMSO} \\
\mathrm{Ml}\end{array}$ & $\begin{array}{c}\text { Control group } \\
\mathrm{Ml}\end{array}$ \\
\hline 6.25 & $1.67 \pm 1.05^{*}$ & $4.43 \pm 0.98^{*}$ & $2.00 \pm 0.98^{*}$ & $2.00 \pm 0.86^{*}$ & $22.70 \pm 1.81$ \\
12.5 & $1.33 \pm 0.20^{*}$ & $3.43 \pm 0.40^{*}$ & $1.03 \pm 0.23^{*}$ & $1.50 \pm 0.78^{*}$ & \\
25 & $0.87 \pm 0.40^{*}$ & $1.77 \pm 0.35^{*}$ & $0.87 \pm 0.15^{*}$ & $0.27 \pm 0.25^{*}$ & \\
50 & $0.43 \pm 0.11^{*}$ & $0.70 \pm 0.17^{*}$ & $0.47 \pm 0.05^{*}$ & $0.20 \pm 0.26^{*}$ & \\
\hline
\end{tabular}

Data are expressed in terms of percentages. SD: Standard deviation; MI: Mitotic index; Significant difference compared to the control group: * $p<0.0001$, EtBr: Ethidium bromide; DMSO: Dimethyl sulphoxide

TABLE 3. The results of the genotoxicity and cytotoxicity in Allium cepa root tip cells exposed to different concentrations of the test compounds (mean \pm SD)

\begin{tabular}{|c|c|c|c|c|c|c|c|c|}
\hline \multirow{2}{*}{$\begin{array}{l}\text { Test } \\
\text { compounds } \\
(\mu \mathrm{g} / \mathrm{ml})\end{array}$} & \multirow[t]{2}{*}{ Micronuclei } & \multirow[t]{2}{*}{ Stickiness } & \multicolumn{4}{|c|}{ Abnormal ana-telophases } & \multirow{2}{*}{$\begin{array}{l}\text { Apoptotic } \\
\text { cells }\end{array}$} & \multirow[t]{2}{*}{ Necrotic cells } \\
\hline & & & Bridges & Vagrants & $\begin{array}{l}\text { Chromosome } \\
\text { missegregation }\end{array}$ & Multipolar & & \\
\hline \multicolumn{9}{|l|}{$\mathrm{Na}\left[\mathrm{Ru}\left(\mathrm{L}_{2}\right)_{2}\right]$} \\
\hline 6.25 & $0.33 \pm 0.57$ & $1.67 \pm 1.15$ & $0.67 \pm 0.57$ & n.o. & n.o. & n.o. & n.o. & n.o. \\
\hline 12.5 & $0.33 \pm 0.57$ & $1.67 \pm 0.57$ & $0.33 \pm 0.57$ & $1.00 \pm 1.00$ & n.o. & n.o. & n.o. & n.o. \\
\hline 25 & n.o. & $1.33 \pm 1.52$ & n.o. & $0.33 \pm 0.57$ & $0.67 \pm 0.57$ & n.o. & n.o. & n.o. \\
\hline 50 & $0.67 \pm 1.15$ & $1.00 \pm 1.73$ & $0.33 \pm 0.57$ & n.o. & $1.00 \pm 1.15$ & n.o. & $5.67 \pm 1.52^{* *}$ & $12.00 \pm 1.73^{\star \star \star \star}$ \\
\hline \multicolumn{9}{|l|}{$\mathrm{Na}\left[\mathrm{RuCl}_{2}\left(\mathrm{~L}^{1}\right)\right.$ 2] } \\
\hline 6.25 & n.o. & $7.00 \pm 1.73^{\star * *}$ & $2.33 \pm 0.57^{\star *}$ & $2.67 \pm 1.52$ & $4.33 \pm 2.51^{\star *}$ & $1.67 \pm 2.08$ & n.o. & n.o. \\
\hline 12.5 & $3.00 \pm 1.00^{*}$ & $3.33 \pm 1.52$ & n.o. & $1.00 \pm 1.00$ & $1.33 \pm 0.57$ & $1.00 \pm 1.00$ & $3.00 \pm 2.00$ & n.o. \\
\hline 25 & $4.33 \pm 0.57^{\star *}$ & n.o. & $1.00 \pm 1.00$ & n.o. & n.o. & n.o. & $6.33 \pm 2.51^{* *}$ & $5.00 \pm 2.00^{*}$ \\
\hline 50 & $2.67 \pm 1.52^{*}$ & $1.33 \pm 0.57$ & $3.33 \pm 0.57^{* * *}$ & n.o. & n.o. & n.o. & $8.67 \pm 2.51^{* * *}$ & $10.67 \pm 3.51^{* \star *}$ \\
\hline \multicolumn{9}{|l|}{$\mathrm{EtBr}$} \\
\hline 6.25 & n.o. & $6.33 \pm 1.15^{\star \star \star *}$ & $3.67 \pm 1.52^{* *}$ & $0.67 \pm 0.57$ & n.o. & n.o. & n.o. & $1.67 \pm 0.57$ \\
\hline 12.5 & n.o. & $1.67 \pm 1.57$ & $1.33 \pm 0.57$ & n.o. & n.o. & n.o. & n.o. & $2.67 \pm 1.52$ \\
\hline 25 & n.o. & $3.33 \pm 1.15^{*}$ & $4.00 \pm 1.73^{* *}$ & n.o. & n.o. & n.o. & n.o. & $4.33 \pm 0.57^{\star *}$ \\
\hline 50 & n.o. & $2.33 \pm 0.57$ & $0.67 \pm 0.57$ & n.o. & n.o. & n.o. & n.o. & $9.00 \pm 1.73^{\star \star \star *}$ \\
\hline \multicolumn{9}{|l|}{ DMSO } \\
\hline 6.25 & n.o. & $0.33 \pm 0.57$ & $067 \pm 1.15$ & n.o. & $9.33 \pm 2.51^{* * *}$ & n.o. & n.o. & n.o. \\
\hline 12.5 & n.o. & $1.00 \pm 1.73$ & $0.67 \pm 0.57$ & n.o. & $6.00 \pm 3.60^{*}$ & n.o. & n.o. & n.o. \\
\hline 25 & $2.67 \pm 1.15^{\star *}$ & n.o. & $1.33 \pm 1.15$ & n.o. & n.o. & n.o. & n.o. & $2.67 \pm 0.57^{\star \star *}$ \\
\hline 50 & n.o. & n.o. & n.o. & n.o. & n.o. & n.o. & n.o. & $6.33 \pm 1.15^{\star \star \star *}$ \\
\hline Control group & $0.33 \pm 0.57$ & $0.67 \pm 0.57$ & n.o. & $0.67 \pm 1.15$ & n.o. & n.o. & n.o. & n.o. \\
\hline
\end{tabular}

n.0.: Not observed; SD: Standard deviation; Significant difference compared to the control group: ${ }^{*} p<0.05 ;{ }^{* *} p<0.01$; ${ }^{* * *} p<0.001$; ${ }^{* * * *} p<0.0001$, EtBr: Ethidium bromide; DMSO: Dimethyl sulphoxide

molecules containing an azomethine group $(-\mathrm{HC}=\mathrm{N}-)$ and having excellent chelating properties to bind many metals in stable complexes. $\mathrm{Ru}(\mathrm{II})$ and $\mathrm{Ru}(\mathrm{III})$ generally have preferential affinity toward N-donor ligands, including the azomethine group. The biological activity of metal complexes is determined by the transport mode, activation, and redox potential which must be taken into account in designing the process of new compounds (32). The complex denoted as $\mathrm{Na}\left[\mathrm{RuCl}_{2}\left(\mathrm{~L}^{1}\right)_{2}\right]$ contains $\mathrm{Ru}$ atom coordinated by two chlorides as easily leaving group and two O,N-Schiff bases derived from 5-chlorosalicylaldehyde and aniline. The compound has been described as antibacterial agent, especially against Staphylococcus aureus (33). It has been also described as a complex with weak to moderate 


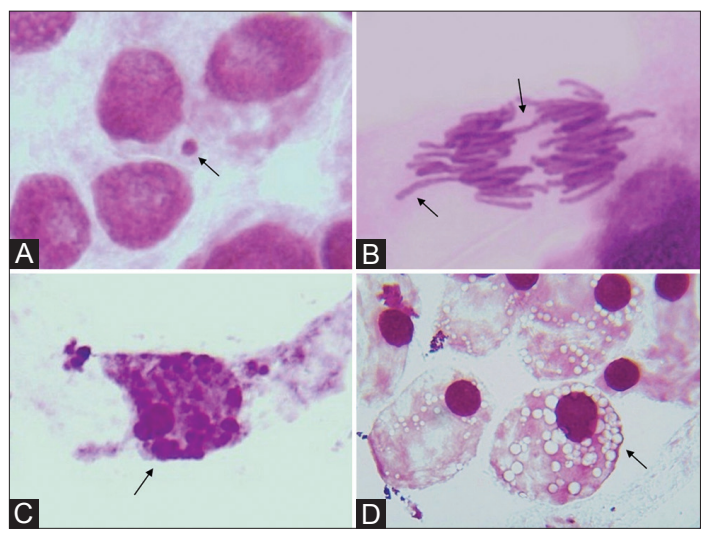

FIGURE 1. Representative images of various chromosome aberrations observed in Allium cepa meristematic cells. (A) Micronucleus caused by $50 \mu \mathrm{g} / \mathrm{ml} \mathrm{Na}\left[\mathrm{RuCl}_{2}\left(\mathrm{~L}^{1}\right)_{2}\right]$ in an interphase cell. (B) Chromosome bridge and vagrant chromosomes in anaphase induced by $12.5 \mu \mathrm{g} / \mathrm{ml} \mathrm{Na}\left[\mathrm{Ru}\left(\mathrm{L}^{2}\right)_{2}\right]$. (C) Apoptotic cell after treatment with $50 \mu \mathrm{g} / \mathrm{ml} \mathrm{Na}\left[\mathrm{RuCl}_{2}\left(\mathrm{~L}^{1}\right)_{2}\right]$. (D) Necrosis following exposure to $50 \mu \mathrm{g} / \mathrm{ml} \mathrm{Na}\left[\mathrm{RuCl}_{2}\left(\mathrm{~L}^{1}\right)_{2}\right]$.

antiproliferative effect in vitro for several primary tumor cell lines (34). In $\mathrm{Na}\left[\mathrm{Ru}\left(\mathrm{L}^{2}\right)_{2}\right]$, the $\mathrm{Ru}$ atom is coordinated by two tridentate Schiff bases through two phenolic oxygen and azomethine nitrogen atoms. Both complexes are resistant toward hydrolysis and are able to moderately bind calf thymus DNA (CT DNA) by non-covalent mode. However, no data are available for genotoxic and cytotoxic properties of both compounds. Since, EtBr is a wellknown intercalator, we comparatively used it in the present study along with our ruthenium complexes. Although, EtBr was more extensively investigated in terms of its mutagenic potentials and anti-mitotic activities, there are no data available in the literature about those effects in plants. This study has provided background data that contribute to the assessment and better understanding of the genotoxic and cytotoxic properties of these substances.

Since the different effects were observed depending on the substance, tested concentration, and endpoint measured, these three chemicals may, in a certain way, be considered as genotoxic, cytotoxic, and cytostatic substances. The results of the analysis of macroscopic parameters showed that root growth of the treated tips was reduced after all treatments $\left(\mathrm{Na}\left[\mathrm{RuCl}_{2}\left(\mathrm{~L}^{1}\right)_{2}\right], \mathrm{Na}\left[\mathrm{Ru}\left(\mathrm{L}^{2}\right)_{2}\right], \mathrm{EtBr}\right.$, and DMSO) and tested concentrations as compared to the controls (Table 1). Furthermore, all concentrations of each tested substance in the present study significantly lowered the MI values (Table 2) when compared to the control set. It is demonstrated that root growth is regulated by the processes of cell division in actively dividing root meristematic zone. Subsequently root tip elongation occurs, where root growth can be disturbed by chemical inhibition and/or disruption (28). Additionally, the reduction in the MI values could be due to the inhibition of DNA synthesis, or blocking the G2 phase of the cell cycle, which prevents the cell to start mitosis (35). Clearly, the results of the present study confirm that all tested compounds disrupted these molecular events during cell division leading to the reduction of the MI values, which finally resulted in the inhibition of root growth in the treated root tips.

The reduced MI and root growth of $A$. cepa were accompanied by several chromosomal aberrations observed in the present study. Chromosomal alterations observed in the treatments were: sticky chromosomes, micronuclei, chromosomal bridges, vagrant chromosomes, chromosome missegregation, and multipolarity.

Chromosome stickiness is the major and most frequent alteration observed in this study. Stickiness could have been caused by adhesion or dissolution of chromosomal proteins $(36,37)$. During the cell division, chromosome breakage leads to the micronuclei formation, which is not incorporated in the main nuclei. Therefore, the frequency of micronuclei reflects toxic effects of tested chemicals (38). Another commonly observed abnormality in the treated cells was chromosomal bridge. Chromosomal bridges arise from chromatid and/or chromosome breaks and fusion, and are considered as endpoints of clastogenic effects $(39,40)$. According to Rank (41), vagrant chromosomes are indicators of spindle poisoning and disturbance. Similarly, impaired chromosome segregation may also indicate mitotic spindle disturbance (28). Cells with more than two centrosomes can undergo anaphase with multipolar spindles and segregate chromosomes irregularly to more than two daughter cells. This lethal event selectively targets the cancer cells with extra centrosomes, avoiding normal cells with two centrosomes (42).

The $\mathrm{Na}\left[\mathrm{RuCl}_{2}\left(\mathrm{~L}^{1}\right)_{2}\right]$ treatments showed statistically significant incidence of spindle disturbances 
like chromosome missegregation. In addition, many clastogenic abnormalities such as stickiness, chromosomal bridges as well as micronuclei were observed suggesting its destructive impact on chromosomes. The same chromosome aberrations (micronuclei and chromosome missegregation) were significantly induced by $\mathrm{Na}\left[\mathrm{RuCl}_{2}\left(\mathrm{~L}^{1}\right)_{2}\right]$ and DMSO. Therefore, we cannot exclude cumulative effects of DMSO and $\mathrm{Na}\left[\mathrm{RuCl}_{2}\left(\mathrm{~L}^{1}\right)_{2}\right]$ on these chromosomal abnormalities. The chromosomal aberrations induced by $\mathrm{Na}\left[\mathrm{Ru}\left(\mathrm{L}^{2}\right)_{2}\right]$ are similar to those induced by $\mathrm{Na}\left[\mathrm{RuCl}_{2}\left(\mathrm{~L}^{1}\right)_{2}\right]$, but the differences in the frequency of genotoxic alterations induced by $\mathrm{Na}\left[\mathrm{Ru}\left(\mathrm{L}^{2}\right)_{2}\right]$ were not significant as compared to the control group. These non-significant results for $\mathrm{Na}\left[\mathrm{Ru}\left(\mathrm{L}^{2}\right)_{2}\right]$ do not exclude other relevant toxicological effects of this compound. The inhibition of mitotic activity and root growth in this study suggests that this substance may also cause toxic effects in plants. Based on these results, we could assume that observed differences between the two ruthenium complexes might be due to their different structures.

On the other hand, $\mathrm{EtBr}$ significantly induced sticky metaphases and chromosomal bridges, which also confirms its disruptive impact on chromosome structure. Interestingly, these findings indicate that there are no cumulative effects observed between EtBr and DMSO (Table 3).

While necrosis is usually seen as a cell rupture caused by exogenous damage, apoptosis is a process consisting of coordinated molecular events leading to morphological changes, removing unnecessary or damaged cells $(43,44)$. DNA damage can induce programmed cell death. Hence, the frequencies of apoptosis and necrosis in the treated $A$. cepa cells were markers of cytotoxicity of the tested compounds in the present study.

As for the cytotoxicity endpoints analyzed, the two ruthenium complexes showed significant dose-dependent increase in the frequencies of apoptotic and necrotic cells. EtBr demonstrated similar cytotoxic effects but only with regard to the number of necrotic cells. This indicated that a significant number of $\mathrm{EtBr}$ and DMSO treated root tip cells of $A$. cepa were eliminated by necrosis. We also observed a significant number of necrotic cells after the treatment with both ruthenium complexes, but we are not sure whether necrosis was caused by the tested ruthenium complexes or by DMSO, which was used as solvent. In addition, we had a significant number of apoptotic cells after the treatment with the tested ruthenium complexes. On the other hand, no apoptosis was observed in the $\mathrm{EtBr}$ and DMSO treated meristematic cells of $A$. cepa. This represents very interesting evidence, which corresponds with previously described antiproliferative effect of $\mathrm{Na}\left[\mathrm{RuCl}_{2}\left(\mathrm{~L}^{1}\right)_{2}\right]$ on primary colon tumor cells (34).

It is generally accepted that the cytotoxicity of ruthenium complexes is associated with their ability to bind to DNA (45). Considering DNA as a target molecule, several in vitro studies have confirmed DNA-binding properties of Ru compounds and strongly suggested direct correlation between cytotoxic activity of such complexes and binding to DNA (14). The ruthenium complex cis-(dichloro) tetrammineruthenium(III)chloride or cis-[Ru$\left.\mathrm{Cl}_{2}\left(\mathrm{NH}_{3}\right)_{4}\right] \mathrm{Cl}$ demonstrated cytostatic activity in studies conducted using human and mice tumor cells, by inhibiting the progression of the tumor cell cycle and inducing apoptosis (46), which corresponded with our results. Cytotoxic effects of the cis- $\left[\mathrm{RuCl}_{2}\left(\mathrm{NH}_{3}\right)_{4}\right] \mathrm{Cl}$ were reported in $\mathrm{BALB} / \mathrm{c}$ mice transplanted with Sarcoma 180 cells (14). Based on our findings, we cannot say whether the cytotoxic effects of the two tested ruthenium complexes are a consequence of their ability to react only with DNA, or with some cell proteins included in the cell cycle, or with both. It has been clearly demonstrated that ruthenium complexes form hydrogen bonds with proteins $(47,48)$. The induction of apoptosis by $\mathrm{Na}\left[\mathrm{RuCl}_{2}\left(\mathrm{~L}^{1}\right)_{2}\right]$ at 25 and $50 \mu \mathrm{g} / \mathrm{ml}$ concentrations may be associated with the structure of this complex in which the $\mathrm{Ru}$ (III) atom is coordinated with two chlorides, which hydrolyze in aqueous solution making two active positions for possible binding to proteins. The complex $\mathrm{Na}\left[\mathrm{Ru}\left(\mathrm{L}^{2}\right)_{2}\right]$ is not coordinated with easily leaving ligands. Therefore, the difference in activity between the two compounds can be attributed to the different ability to bind proteins, especially considering that the constants of non-covalent binding to CT DNA for both compounds are close (about $\left.10^{4} \mathrm{M}^{-1}\right)(29,30)$. 


\section{CONCLUSION}

The results of the present study point out that $\mathrm{Na}\left[\mathrm{RuCl}_{2}\left(\mathrm{~L}^{1}\right)_{2}\right], \mathrm{Na}\left[\mathrm{Ru}\left(\mathrm{L}^{2}\right)_{2}\right]$, DMSO as well as $\mathrm{EtBr}$ possess highly genotoxic and cytotoxic potential. All tested compounds showed clear cytostatic effects in onion root tip cells. Observed alterations in this study such as micronuclei, sticky chromosomes, chromosomal bridges, vagrant chromosomes, chromosome missegregation, and multipolarity show that $\mathrm{Na}\left[\mathrm{RuCl}_{2}\left(\mathrm{~L}^{1}\right)_{2}\right], \mathrm{Na}\left[\mathrm{Ru}\left(\mathrm{L}^{2}\right)_{2}\right]$, DMSO and $\mathrm{EtBr}$ can be considered as clastogenic agents with significant potential for disruption of mitotic spindle.

Based on our results and described antiproliferative effects, $\mathrm{Na}\left[\mathrm{RuCl}_{2}\left(\mathrm{~L}^{1}\right)_{2}\right]$ and $\mathrm{Na}\left[\mathrm{Ru}\left(\mathrm{L}^{2}\right)_{2}\right]$ could be interesting as potential anticancer substances, which suggests that it is necessary to conduct further examinations on tumor cell lines and animal models to confirm our findings.

\section{CONFLICT OF INTEREST}

The authors declare no conflict of interest.

\section{REFERENCES}

1. Kostova I. Ruthenium complexes as anticancer agents. Curr Med Chem. 2006;13(9):1085-107.

http://dx.doi.org/10.2174/092986706776360941.

2. Sava G, Zorzet S, Giraldi T, Mestroni G, Zassinovich G. Antineoplastic activity and toxicity of an organometallic complex of ruthenium(II) in comparison with cis-PDD in mice bearing solid malignant neoplasms. Eur $\mathrm{J}$ Cancer Clin Oncol. 1984;20(6):841-47. http://dx.doi.org/10.1016/0277-5379(84)90223-2.

3. Sava G, Bergamo A. Ruthenium-based compounds and tumour growth control (review). Int J Oncol. 2000;17(2):353-65.

http://dx.doi.org/10.3892/ijo.17.2.353.

4. Sharma AR, Gangrade DM, Bakshi SD, John JS. Ruthenium complexes: Potential candidate for anti-tumour activity. Int J ChemTech Res. 2014;6(1):828-37.

5. Allardyce CS, Dyson PJ. Ruthenium in medicine: Current clinical uses and future prospects. Platin Met Rev. 2001;45(2):62-9.

6. Antonarakis ES, Emadi A. Ruthenium-based chemotherapeutics: Are they ready for prime time? Cancer Chemother Pharmacol. 2010;66(1):1-9. http://dx.doi.org/10.1007/s00280-010-1293-1.

7. Gagliardi R, Sava G, Pacor S, Mestroni G, Alessio E. Anti-metastatic action and toxicity on healthy tissues of $\mathrm{Na}[$ trans-RuCl4(DMSO)Im] in the mouse. Clin Exp Metastasis. 1994;12(2):93-100.

http://dx.doi.org/10.1007/BF01753975.

8. Bergamo A, Masi A, Dyson PJ, Sava G. Modulation of the metastatic progression of breast cancer with an organometallic ruthenium compound. Int J Oncol. 2008;33(6):1281-9.

9. Anitha P, Chitrapriya N, Jang YJ, Wiswanathamurthi P. Synthesis, characterization, DNA interaction, antioxidant and anticancer activity of new ruthenium(II) complexes of thiosemicarbazone/semicarbazone bearing 9,10-phenanthrenequinone. J Photochem Photobiol. 2013;129(C):17-26. http://dx.doi.org/10.1016/j.jphotobiol.2013.09.005.

10. Levina A, Aitken JB, Gwee YY, Lim ZJ, Liu M, Singharay AM, et al. Biotransformation of anticancer ruthenium(III) complexes: An X-ray absorption spectroscopic study. Chem Eur J. 2013;19(11):3609-19. http://dx.doi.org/10.1002/chem.201203127.

11. Kratz F, Messori L. Spectral characterization of ruthenium(III) transfferin. J Inorg Biochem. 1993;49(2):79-82.

http://dx.doi.org/10.1016/0162-0134(93)85017-3.

12. Pongratz M, Schluga P, Jakupec MA, Arion VB, Hartinger CG, Allmaier G, et al. Transfferin binding and transfferin-mediated cellular uptake of the ruthenium coordination compound KP1019, studied by means of AAS, ESI-MS and CD spectroscopy. J Anal At Spectrom. 2004;19(1):46-51. http://dx.doi.org/10.1039/b309160k.

13. Bratsos I, Jedner S, Gianferrara T, Alessio E. Ruthenium anticancer compounds: Challenges and expectations. Chimia. 2007;61(11):692-7.

http://dx.doi.org/10.2533/chimia.2007.692.

14. Menezes CS, de Paula Costa LC, de Melo Rodrigues Avila V, Ferreira MJ, Vieira CU, Pavanin LA, et al. Analysis in vivo of antitumor activity, cytotoxicity and interaction between plasmid DNA and the cis-dichloro-tetra-amine-ruthenium(III) chloride. Chem Biol Interact. 2007;167(2):116-24.

http://dx.doi.org/10.1016/j.cbi.2007.02.003.

15. Scholl M, Ding S, Lee CW, Grubbs RH. Synthesis and activity of a new generation of Ruthenium-based olefin metathesis catalysts coordinated with 1, 3-Dimesityl-4, 5-dihydroimidazol-2-ylidene Ligands §. Organic Lett. 1999;1(6):953-6.

http://dx.doi.org/10.1021/01990909q.

16. Alessio E, Mestroni G, Bergamo A, Sava G. Ruthenium antimetastatic agents. Curren Topics Med Chem. 2004;4(15):1525-35.

http://dx.doi.org/10.2174/1568026043387421.

17. Hartinger CG, Jakupec MA, Zorbas-Seifried S, Groessl M, Egger A Berger W, et al. KP1019, a new redox-active anticancer agent-Preclinical development and results of a clinical phase I study in tumor patients. Chem Bio Div. 2008:5(10):2140-55.

http://dx.doi.org/10.1002/cbdv.200890195.

18. da Silva CM, da Silva DL, Modolo LV, Alves RB, de Resende MA, Martins CV, et al. Schiff bases: A short review of their antimicrobial activities. J Adv Res. 2011;2(1):1-8.

http://dx.doi.org/10.1016/j.jare.2010.05.004.

19. Kumar S, Dhar DN, Saxena PN. Applications of metal complexes of Schiff bases-A review. J Sci Ind Res. 2009;68(3):181-7.

20. Nafisi S, Saboury AA, Keramat N, Neault JF, Tajmir-Riahi HA. Stability and structural features of DNA intercalation with ethidium bromide, acridine orange and methylene blue. J Mol Str. 1997;827(1-3):35-43.

http://dx.doi.org/10.1016/j.molstruc.2006.05.004.

21. Karacan $P$, Okay O. Ethidium bromide binding to DNA cryogels. Reac Funct Poly. 2013;73(3):442-50.

http://dx.doi.org/10.1016/j.reactfunctpolym.2012.11.014.

22. Vergani L, Mascetti G, Gavazzo P, Nikolini C. Ethidium Bromide intercalation and chromatine structure: A thermal analysis. Thermochimica Acta. 1997;294(2):193-204.

http://dx.doi.org/10.1016/S0040-6031(96)03123-1.

23. Alonso A, Almendral MJ, Curto Y, Criado JJ, Rodriguez E, Manzano JL. Determination of the DNA-binding characteristics of ethidium bromide, proflavine, and cisplatin by flow injection analysis: Usefulness in studies of antitumor drugs. Anal Biochem. 2006;355(2):157-64.

http://dx.doi.org/10.1016/j.ab.2006.06.004

24. Fiskesjo $\mathrm{G}$. The Allium test as a standard in environmental monitoring. Herreditas. 1985;102(1):99-112. 
http://dx.doi.org/10.1111/j.1601-5223.1985.tb00471.x.

25. Yildiz M, Cigerci $\mathbb{H}$, Konuk M, Fidan AF, Terzi $H$. Determination of genotoxic effects of copper sulphate and cobalt chloride in Allium cepa root cells by chromosome aberration and comet assays. Chemosphere. 2009;75(7):934-8.

http://dx.doi.org/10.1016/j.chemosphere.2009.01.023.

26. Saxena PN, Chauhan LKS, Gupta SK. Cytogenetic effects of commercial formulation of cypermethrin in root meristem cells of Allium sativum: Spectroscopic basis of chromosome damage. Toxicology. 2005;216(2-3):244-52.

http://dx.doi.org/10.1016/j.tox.2005.08.008.

27. Saxena PN, Gupta SK, Murthy RC. Carbofuran induced cytogenetic effects in root meristem cells of Allium cepa and Allium sativum: A spectroscopic approach for chromosome damage. Pestic Biochem Phys. 2010;96(2):93-100. http://dx.doi.org/10.1016/j.pestbp.2009.09.006.

28. Herrero O, Perez Martin JM, Fernandez Freire P, Carvajal Lopez L, Peropadre A, Hazen MJ. Toxicological evaluation of three contaminants of emerging concern by use of the Allium cepa test. Mutat Res. 2012;743(1-2):20-4. http://dx.doi.org/10.1016/j.mrgentox.2011.12.028.

29. Ljubijankić N, Zahirović A, Turkušić E, Kahrović E. DNA binding properties of two Ruthenium(III) complexes containing Schiff bases derived from salicylaldehyde: Spectroscopic and electrochemical evidence of CT DNA intercalation. Croat Chem Acta. 2013;86(2):215-22. http://dx.doi.org/10.5562/cca2216.

30. Kahrović E, Zahirović A, Turkušić E. Calf thymus DNA intercalation by anionic $\mathrm{Ru}(\mathrm{III})$ complexes containing tridentate Schiff bases derived from 5-X-Substituted salicyladehyde and 2- Aminophenol. J Chem Chem Eng. 2014;8(4):335-43.

31. Fiskesjo G. Allium test 1: A 2-3 day plant test for toxicity assessment by measuring the mean root growth of onions (Allium cepa L.). Environ Toxicol Water Qual. 1993;8(4):461-70.

http://dx.doi.org/10.1002/tox.2530080410.

32. Kahrovic E. Chemical feature of inorganic compounds as anticancer agents. Health Med. 2011;5(5):1112-6.

33. Kahrović $E$, Bektaš $S$, Turkušić $E$, Zahirović A. Evidence on antimicrobial activity of Sodium dichloro-bis[N-phenyl-5-chlorosalicylideneiminato-N,O]ruthenate(III) against gram positive bacteria. SYLWAN. 2014;158(5):482-93.

34. Kahrović E, Kraljević, Pavelić S. Antiproliferative effect and selectivity of Sodium dichloro-bis [Nphenyl-5-chloro-salicylideneiminato-N,O]ruthenate(III) in vitro. Int J Pharm Pharm Sci. 2015;7(1):86-8.

35. Renjana PK, Anjana S, Thoppil JE. Evaluation of genotoxic effects of baking powder and monosodium glutamate using Allium cepa assay. Int $\mathrm{J}$ Pharm Pharm Sci. 2013;5(2):311-5.
36. Mercykutty VC, Stephen J. Adriamycin induced genetic toxicity as demonstrated by Allium test. Cytologia. 1980;45(4):769-77.

http://dx.doi.org/10.1508/cytologia.45.769.

37. Patil BC, Bhat GI. A comparative study on $\mathrm{MH}$ and EMS in the induction of chromosome aberration on root meristem of Clitoria ternate L. Cytologia. 1992;57(2):259-64.

http://dx.doi.org/10.1508/cytologia.57.259.

38. Nefic $\mathrm{H}$, Handzic I. The effect of age, sex, and lifestyle factors on micronucleus frequency in peripheral blood lymphocytes of the Bosnian population. Mutat Res. 2013;753(1):1-11.

http://dx.doi.org/10.1016/j.mrgentox.2013.03.001.

39. Young SW, Young PW. Effect of plant growth regulators on mitotic chromosomes. The Nucleus. 1993;36:109-13.

40. Turkoglu S. Genotoxicity of five food preservatives tested on root tips of Allium cepa L. Mutat Res. 2007;626(1-2):4-14. http://dx.doi.org/10.1016/j.mrgentox.2006.07.006.

41. Rank J. The method of Allium anaphase-telophase chromosome aberration assay. Ekologija (Vilnius). 2003;1:38-42.

42. Galimberti F, Thompson SL, Ravi S, Compton DA, Dimitrovsky E. Anaphase catastrophe is a target for cancer therapy. Clin Cancer Res. 2011;17(6):1218-22. http://dx.doi.org/10.1158/1078-0432.CCR-10-1178.

43. Kalcheva VP, Dragoeva AP, Kalchev KN, Enchev DD. Cytotoxic and genotoxic effects of Br-containing oxaphosphole on Allium cepa L. root tip cells and mouse bone marrow cells. Gen. Mol Biol. 2009;32(2):389-93.

http://dx.doi.org/10.1590/\$1415-47572009000200028.

44. Stepanek O, Brdicka T, Angelisova P, Horvath O, Spicka J, Stockbauer P, et al. Interaction of late apoptotic and necrotic cells with Vitronectin. PLoS One. 2011;6(5):e19243.

http://dx.doi.org/10.1371/journal.pone.0019243.

45. Brabec V, Novakova O. DNA binding mode of ruthenium complexes and relationship to tumor cell toxicity. Drug Resist Upd. 2006;9(3):111-22. http://dx.doi.org/10.1016/j.drup.2006.05.002.

46. Ribeiro Ade S, da Silva CC, Pereira Fde C, Lima AP, Vilanova-Costa CA, Aguiar SS, et al. Mutagenic and genotoxic effects of cis-(dichloro)tetraammineruthenium(III) chloride on human peripheral blood lymphocytes. Biol Trace Elem Res. 2009;130(3):249-61. http://dx.doi.org/10.1007/s12011-009-8334-9.

47. Hazarika P, Bezbaruah B, Deka J, Deka RP, Medhi OK, Medhi C. The features of protein binding by ruthenium complexes: docking, force field and QM/MM studies. IJRRAS. 2013;14(1):64-74.

48. Kratz F, Hartmann M, Keppler B, Messori L. The binding properties of two antitumor ruthenium(III) complexes to apotransferrin. J Biol Chem. 1994;269(4):2581-8. 